\title{
Characterizing the Particle Composition and Cloud Condensation Nuclei from Shipping Emission in Western Europe
}

Chenjie Yu, Dominika Pasternak, James Lee, Mingxi Yang, Thomas Bell, Keith Bower, Huihui Wu, Dantong Liu, Chris Reed, Stéphane Bauguitte, Sam Cliff, Jamie Trembath, Hugh Coe,* and James D. Allan*

Cite This: https://dx.doi.org/10.1021/acs.est.0c04039

Read Online

ACCESS | 네 Metrics \& More | 回 Article Recommendations | st Supporting Information

ABSTRACT: Commercial shipping is considered as an important source of air pollution and cloud condensation nuclei $(\mathrm{CCN})$. To assess the climatic and environmental impacts of shipping, detailed characterization of ship plumes near the point of emission and understanding of ship plume evolution further downwind are essential. This airborne measurement study presents the online characterization of particulate phase ship emissions in the region of Western Europe in 2019 prior to new international sulfur emission controls becoming enacted. More than 30 ships from both the sulfur emission control area (SECA) in the English Channel and the open sea (OS) are measured and compared. Ships within the SECA emitted much less sulfate $\left(\mathrm{SO}_{4}\right)$ compared with those at OS. When shifted to a lower apparent fuel sulfur content (FSC) at similar

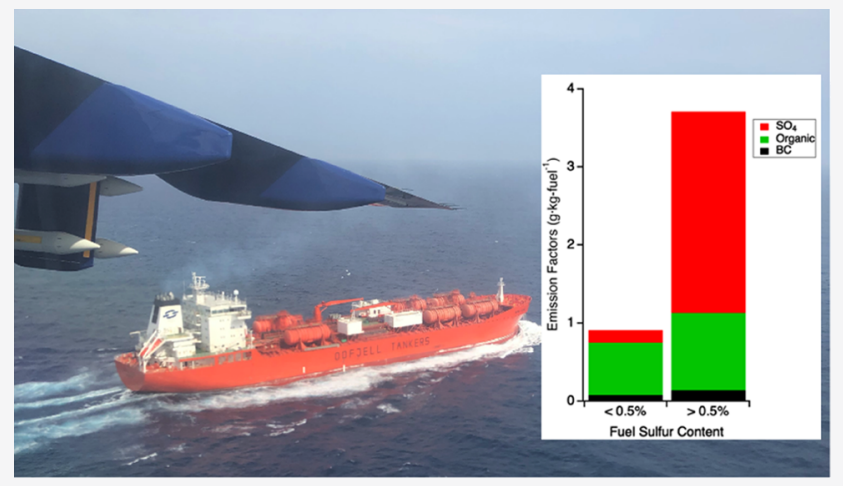
engine loads, the peak of the fresh ship emitting the particle number size distribution shifted from around 60-80 nm in diameter to below $40 \mathrm{~nm}$ in diameter. The emission factors (EFs) of sulfate are predicted to decrease by around $94 \%$ after the 2020 regulation on ship sulfur emission in the open ocean. The EFs of refractory black carbon ( $\mathrm{rBC}$ ) and organic compounds (Org) do not appear to be directly affected by the lower sulfur contents. The total number concentration for condensation nuclei $(\mathrm{CN})>2.5 \mathrm{~nm}$ and $>0.1 \mu \mathrm{m}$ are predicated to be reduced by 69 and $56 \%$, respectively. Measured plume evolution results indicate that the S(IV) to S(VI) conversion rate was around $23.4 \%$ per hour at the beginning of plume evolution, and the $\mathrm{CCN}$ and $\mathrm{CN}>2.5 \mathrm{~nm}$ ratio increased with plume age primarily due to condensation and coagulation. We estimate that the new sulfur emission regulation will lead to a reduction of more than $80 \%$ in CCN from fresh ship emissions. The ship-emitted EFs results presented here will also inform emission inventories, policymaking, climate, and human health studies.

\section{INTRODUCTION}

With the growth of the international seaborne trade in recent decades, commercial shipping emissions have become an important anthropogenic air pollution source. ${ }^{1,2}$ As heavy fuel oil (HFO) with a high sulfur content was one of the dominant shipping fuel types before 2020, commercial shipping had until recently been an ever increasing source of sulfur emissions. ${ }^{3}$ Sulfate derived from shipping emission is a major source of cloud condensation nuclei $(\mathrm{CCN}){ }^{4}$ The total radiative force from global shipping was estimated between -0.3 and $-0.4 \mathrm{~W}$. $\mathrm{m}^{-2}$ on average for 2000 and 2005 , and this contribution is mainly through the alteration of cloud properties, resulting from ship-emitted sulfur aerosols. ${ }^{5}$ Other ship-emitted particles, including black carbon (BC) and organic particulate (Org), may also have an impact on radiative balance due to their absorption and scattering properties. Human health is also significantly influenced by ship emissions, ${ }^{6,7}$ and shiprelated particulate matter emissions may increase lung cancer deaths. ${ }^{8}$ The European coastal regions are among the busiest maritime transport regions globally, where commercial shipping has been estimated to contribute more than $11 \%$ of the observed $\mathrm{PM}_{1}$ (particulate matter with an aerodynamic diameter of less than $1 \mu \mathrm{m}){ }^{9}$

To reduce the health and ecosystem impacts of commercial shipping, the International Maritime Organization (IMO) set a series of increasingly tighter regulations regarding ship-emitted pollutants. As agreed in the MARPOL Annex VI protocol, the fuel sulfur content (FSC) of marine fuels for ships operated on the open sea needs to be less than $3.5 \%$ (by mass) since 2012 . From January 2020, the global cap of the FSC of marine fuels was further reduced to less than $0.5 \%$. The FSC cap is even

Received: June 20, 2020

Revised: November 8, 2020

Accepted: November 9, 2020 


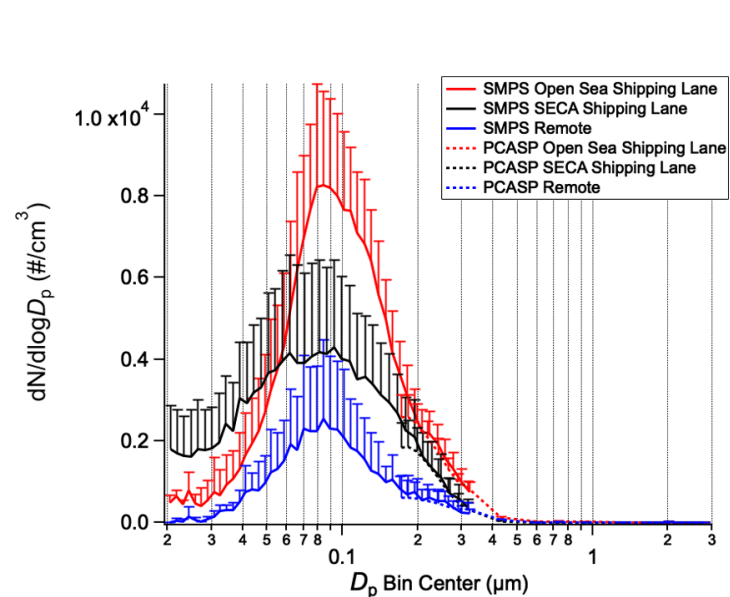

(a)

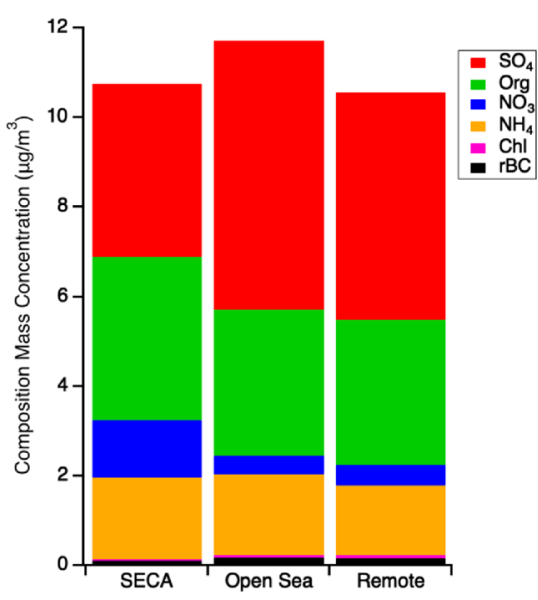

(b)

Figure 1. (a) Background aerosol size distributions (mean \pm standard deviation) for the open sea (OS) shipping lane, sulfur emission control area (SECA) shipping lane, and at $1^{\circ}$ longitude away from the OS shipping lane (remote). (b) Mass concentrations of different aerosol compositions for the OS, SECA, and remote shipping lane background.

stricter within the IMO set sulfur emission control areas (SECAs), which requires the FSC to be less than $0.1 \%$ since 2015. To meet these emission regulations, ships either have to use shipping fuel with ultralow-sulfur fraction such as marine gas oil (MGO) or implement alternative technical methods including the application of ship exhaust gas cleaning systems ("scrubbers").

The emissions of different aerosol components are known to be influenced by many factors. Measurements of ship emissions have been performed in different regions of the world using various platforms. Previous studies demonstrate that switching to a lower FSC fuel together with ship engine load reductions has large benefits on aerosol emissions. ${ }^{10-13}$ On account of the direct and indirect cooling effects of sulfate aerosols, the application of the latest FSC cap may influence the radiative budget, ${ }^{7}$ but more ship-emitted aerosol composition data are needed. ${ }^{14} \mathrm{Up}$ to now, there have been limited numbers of studies reporting detailed emission factors for particulate composition and microphysical properties from ship emissions within the European area, ${ }^{15}$ and most of the studies were performed within the European SECAs, ${ }^{16-18}$ so one should not directly compare different FSCs.

Measurements of ship plumes with consistent methodology from both inside and outside of the SECA allow us to investigate the impact of the sulfur regulation on primary and secondary shipping aerosol emissions and subsequent CCN formation. Here, we present airborne in situ measurements of ship-emitted particle composition within the European region. Particle size distributions together with the physical and chemical properties of particles emitted from ships operated both within and outside the SECA are presented. Comparison between the two regions allows us to assess how the new IMO 2020 regulation will influence the regional aerosol emissions and regional climate forcing. As the new regulation has been in effect since January 1, 2020, this study is likely to be the last direct measurement of ship plumes under the previous $3.5 \%$ FSC regime. This will serve as a basis for comparisons with more modern emissions and also be of use in constructing historical inventories.

\section{EXPERIMENTAL METHODS}

Experiment Overview. The U.K. FAAM Airborne Laboratory BAe-146 research aircraft was used to sample ship plumes over the English Channel and North Atlantic Ocean as part of the Atmospheric Composition and Radiative forcing change due to the International Ship Emissions regulations (ACRUISE) project. The airborne measurement was performed between July 10 and 18, 2019, and the experimental area is presented in Figure S1a. The EDGAR ship-emitted $\mathrm{NO}_{x}$ emission inventory ${ }^{19}$ was also presented to indicate the intensity of the shipping activities. Both the SECA shipping lanes (the English Channel) and the open sea (OS) shipping lanes (near Porto, Portugal) were investigated during the campaign. Over 30 commercial oceangoing vessels were investigated in this study. The ship positions and types measured in this experiment were obtained from an automated information system (AIS) for tracking marine traffic (MarineTraffic; https://www.marinetraffic.com/).

Instrumentation Onboard. The chemical composition of nonrefractory aerosol particles with an aerodynamic diameter below $1 \mu \mathrm{m}$ was measured by an Aerodyne compact time-offlight aerosol mass spectrometer (c-ToF-AMS; Aerodyne). ${ }^{20}$ The AMS was upgraded to the second generation of control and acquisition electronics, and this also included a pressurecontrolled inlet using a replica of the design developed by the University of Colorado at Boulder for the AMS on the NASA DC-8 platform. ${ }^{21}$ Refractory black carbon ( $\mathrm{rBC}$ ) was measured by a single particle soot photometer (SP2; DMT). ${ }^{22}$ The SP2 measured the $\mathrm{rBC}$ particle mass with an optical diameter of 70-850 $\mathrm{nm}$ through the incandescence detectors. A scanning mobility particle sizer (SMPS) system was used to measure the distribution of a particle mobility diameter of $20-350 \mathrm{~nm}^{23} \mathrm{~A}$ passive cavity aerosol spectrometer probe (PCASP-100X; $\mathrm{DMT}$ ) and a cloud droplet probe (CDP; DMT) were further used to measure the size-resolved particle number concentration with particle diameters $\left(D_{\mathrm{p}}\right)$ of $0.1-3$ and $3-10 \mu \mathrm{m}$, respectively. Cloud condensation nuclei $(\mathrm{CCN})$ were measured at a constant supersaturation (SS) of $0.6 \%$, sampled via a shared inlet with a condensation particle counter (CPC; TSI 3786) to measure the number concentration of condensation nuclei $(\mathrm{CN})$. More details of aerosol measurement techniques onboard the FAAM BAe-146 aircraft are described by Taylor 


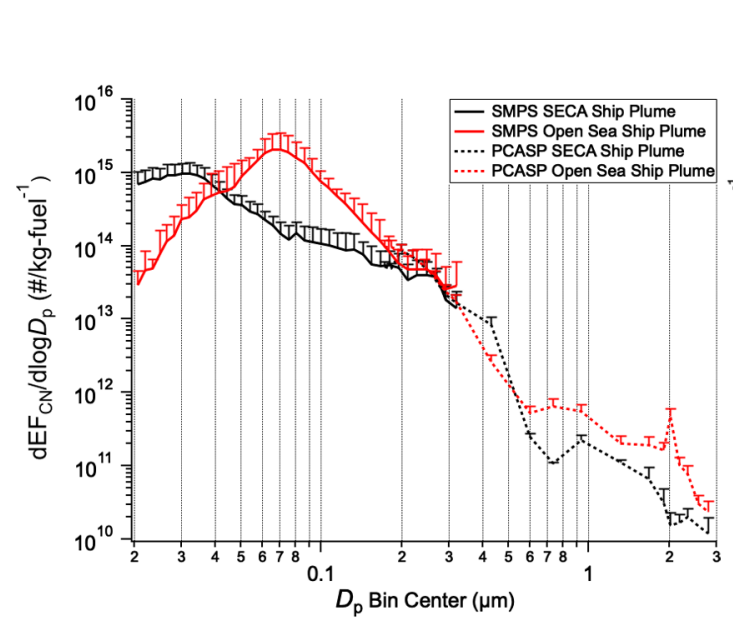

(a)

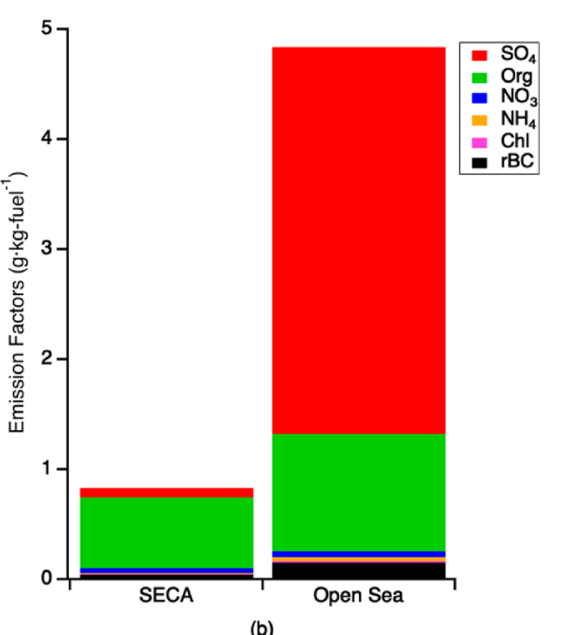

(b)

Figure 2. (a) Size-resolved condensation nuclei emission factor $\left(\mathrm{EF}_{\mathrm{CN}}\right)$ for ship plumes measured at $\mathrm{OS}$ and within the SECA (mean \pm standard deviation for different ships). (b) Average emission factors (EFs) for the same targeted ships measured at OS and SECA shipping lanes.

et al. $^{23} \mathrm{CO}_{2}$ was measured through a fast greenhouse gas analyzer (FGGA; LGR). ${ }^{24}$ Two customized instruments were used to measure $\mathrm{NO}_{x}$ and $\mathrm{SO}_{2}$ by a dual-channel chemiluminescence and pulsed fluorescence analysers. ${ }^{25,26}$ The entire list of measurement techniques onboard is displayed in the Supporting Information.

Plume Identification and Parameters Calculation. The aircraft made two types of ship plume interceptions: the crossplume interception for estimations of fresh pollutant concentrations and emission factors (EFs) (within $\sim 15 \mathrm{~min}$ downwind after emission) and the along plume interception for investigation of the particle size distribution (to accommodate for the $\sim 30 \mathrm{~s}$ scanning time of the SMPS). The ship plume intercepts were identified in the data through increases of the measured $\mathrm{NO}_{x}$ and $\mathrm{CO}_{2}$ mixing ratios. ${ }^{27}$ Figure $\mathrm{S} 1 \mathrm{~b}$ shows an example of a typical cross-plume intercept. The periods immediately before and after the intercept were taken to be the background and subtracted from the intercept data to derive the time-dependent increment that is denoted here with a $\Delta$, e.g., $\Delta \mathrm{CO}_{2}$. The EFs for different measured pollutants and the apparent fuel sulfur content (FSC) were calculated following the method described by Lack et al. ${ }^{28}$ and Aliabadi et al., ${ }^{29}$ and the process is described in the Supporting Information.

The hygroscopicity parameter $(\kappa)$ of the ship-emitted particles was estimated based on the measured aerosol compositions through the method described by Lack et al. ${ }^{10}$ and is further described in the Supporting Information. $\kappa$ is a widely used parameter used to model the solute (Raoult) term in the Köhler equation. ${ }^{30}$

The total $\mathrm{PM}_{1}$ presented in this study was derived from the summation of AMS and SP2 mass concentrations.

\section{RESULTS}

Shipping Lane and Plume Composition Overview. Figure 1 presents the size distribution (Figure 1a) and aerosol compositions (Figure 1b) from the English Channel, which is a busy shipping lane within the SECA $\left(49^{\circ}-50^{\circ} \mathrm{N},-5^{\circ}-0^{\circ} \mathrm{E}\right)$ and at $\mathrm{OS}\left(40^{\circ}-42^{\circ} \mathrm{N},-10.5^{\circ}\right.$ to $\left.-9.5^{\circ} \mathrm{E}\right)$. The marine background size distribution is determined using data obtained from regions more than $1^{\circ}$ longitude away from the OS shipping lane to the west of Portugal and is also presented and referred to as a "remote" area. All the aerosol properties were derived from data collected between 200 and $300 \mathrm{~m}$ above sea level, and all the ship plumes are excluded so that the data are representative of the sea lanes or background regions and are not influenced by specific single plumes. Since they are influenced by the shipping activities, the OS and SECA shipping lane had higher particle number concentrations than the remote background. Though the absolute number concentration is different, the number concentration size distributions of the three regions are similar as all of them have peaked at around $70-80 \mathrm{~nm}$ in $D_{\mathrm{p}}$. A higher fraction of smaller particles between 20 and $50 \mathrm{~nm}$ was observed over the SECA. Comparing the chemical compositions across the three different environments, out of the individual plumes, the SECA shipping lane tended to have the highest $\mathrm{NO}_{3}$ concentration and lowest $\mathrm{SO}_{4}$ concentration. This lower $\mathrm{SO}_{4}$ concentration within the SECA may be due to the stricter sulfur emission regulation. No significant difference was observed among the other components of the particle mass.

The aerosol properties within fresh ship plumes measured within the busy shipping lanes are presented in Figure 3. The size-resolved $\mathrm{EF}_{\mathrm{CN}}$ that averaged over four different ships in the SECA and OS is shown in Figure 3a. The size distributions were measured at $\sim 10-15$ min downwind from the emission point, and the quick condensation of fine particles may contribute to the slight shift toward the large particles. Most of the particles from the OS ship plumes were between 60 and 80 $\mathrm{nm} D_{\mathrm{p}}$, while most of the SECA ship-emitted particles tended to have a smaller size (with $D_{\mathrm{p}}$ smaller than $40 \mathrm{~nm}$ ). The average engine loads for the measured vessels within and outside the SECA were estimated to be $62( \pm 9)$ and $72( \pm 10)$ $\%$, respectively, through the method described by Buffaloe et al. ${ }^{13}$ (as described in the Supporting Information). As only a limited difference of average engine load was observed, this shift of size distributions was mainly contributed by the significant reduction of the apparent FSC. With a lower FSC, the directly emitted $\mathrm{SO}_{4}$ concentrations from ships within the SECA were much less than those in the OS, and this led to a decrease of larger particles. A higher fraction of smaller particles was observed within the SECA ship plumes compared to OS, likely due to a decrease in condensation and coagulation efficiency.

The average EFs of aerosol compositions from these same ships measured close to the emission point are shown in Figure 


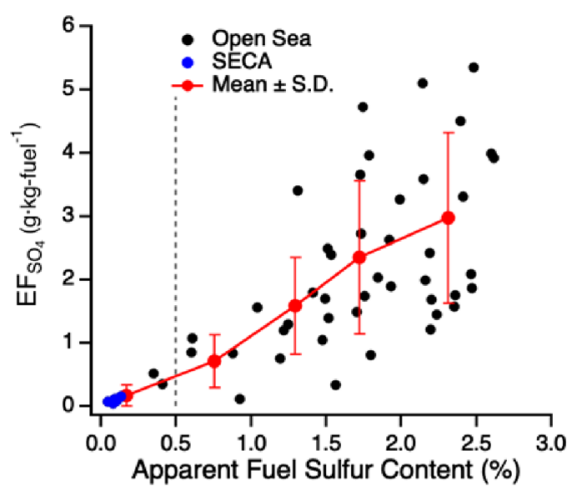

(a)

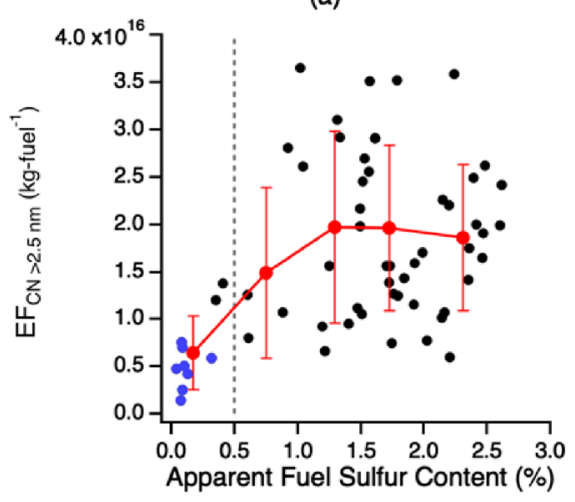

(d)

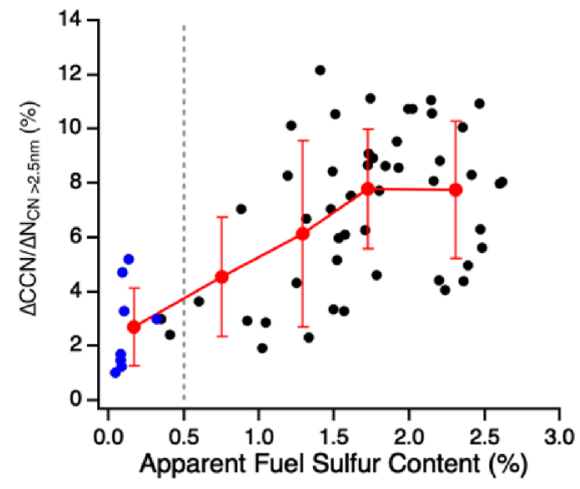

(g)

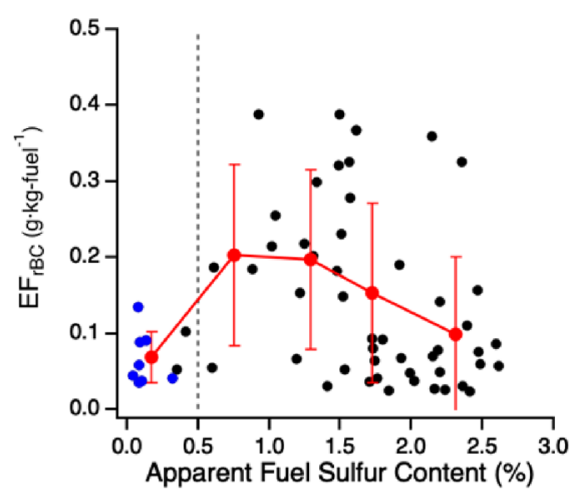

(b)

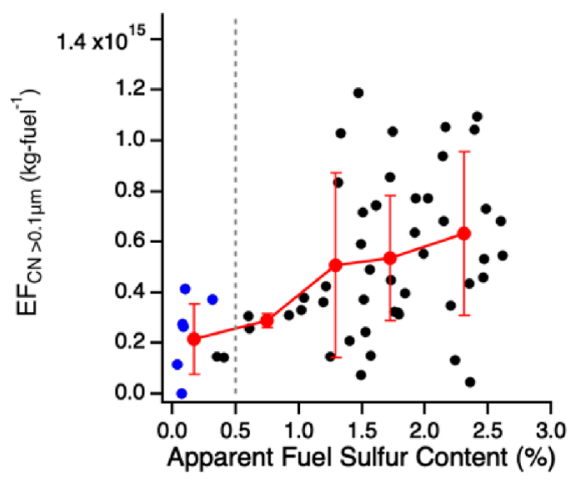

(e)

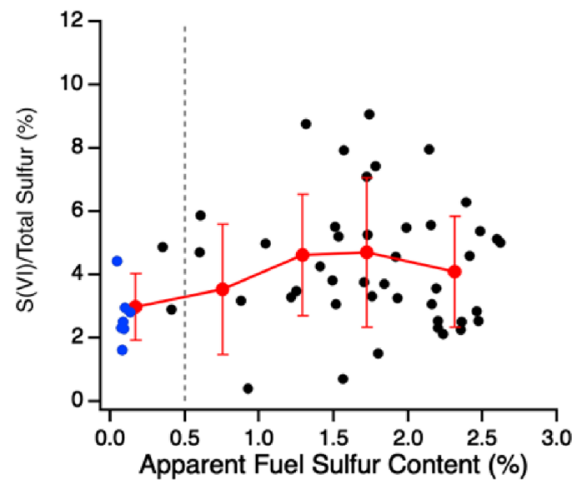

(h)

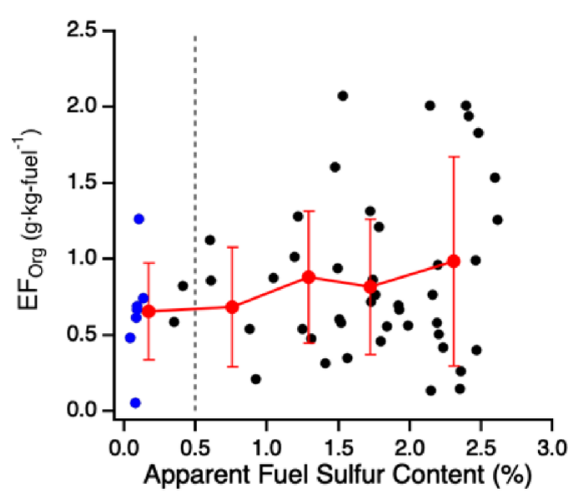

(c)

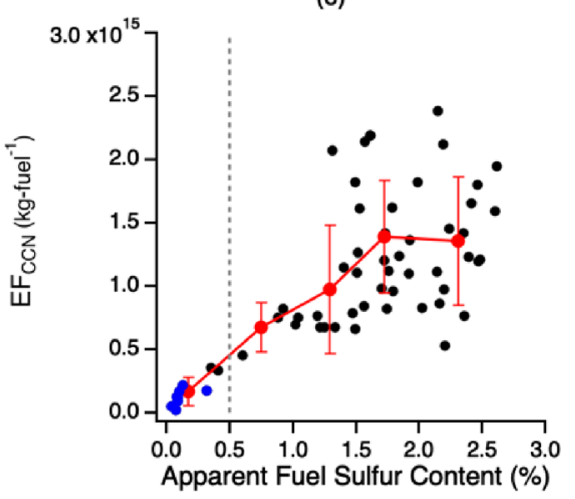

(f)

Figure 3. Emission factor as a function of apparent fuel sulfur content (FSC) for (a) sulfate $\left(\mathrm{SO}_{4}\right)$. (b) Refractory black carbon (rBC). (c) Organic compounds (Org). (d) Total CN $>2.5 \mathrm{~nm}$. (e) Total CN $>0.1 \mu \mathrm{m}$. (f) Cloud condensation nuclei (CCN). (g) Ratio between the number concentrations of $\mathrm{CCN}$ and $\mathrm{CN}>2.5 \mathrm{~nm}\left(\Delta \mathrm{CCN} / \Delta N_{\mathrm{CN}>2.5 \mathrm{~nm}}\right)$. (h) $\mathrm{S}(\mathrm{VI})$ fraction. Each marker represents an individual plume here.

2b. The EFs for the total particle component mass from the SECA ship plumes are much less than those from the OS ship plumes, and this reduction is primarily due to the significant decrease of the $\mathrm{EF}_{\mathrm{SO} 4}$ value. The potential use of scrubbers may lead to slightly higher sulfate emissions within the SECA. $^{31}$ In fresh SECA ship plumes, organics constitute the bulk of the total particle mass, and Org and BC accounted around $86 \%$ of the $\mathrm{PM}_{1}$ emissions within the SECA ship plume. There is no obvious difference in the $\mathrm{EF}_{\text {Org }}$ value between the SECA and OS ship plumes. A slightly higher $\mathrm{EF}_{\mathrm{rBC}}$ value was observed within the OS ship plumes. Minor nitrate, ammonium, and chlorine were observed within the fresh ship plumes.

Emission Factors and Apparent FSC. To better understand the impact of sulfur emission regulations, we next investigate the variations of EFs as a function of the apparent FSC. Only plumes measured close to the emission point below $250 \mathrm{~m}$ above sea level are included here to avoid the complication of aqueous $\mathrm{S}(\mathrm{IV})$ to $\mathrm{S}(\mathrm{VI})$ conversion. Plumes were classified into five FSC bins separated by $0.5 \%$ increments (Figure 4) and the mean value and the standard computed within each bin. As the average engine loads for the measured ships within and outside the SECA are similar (63 $( \pm 8) \%$ on average in the SECA and $74( \pm 10) \%$ on average in the OS), this has not been included as an independent variable. According to our measurements, some ships have already conform to the IMO 2020 level with FSC $<0.5 \%$ (but $>0.1 \%$ ) in the OS. To aid the development of future emission inventories, the EFs over the OS shipping lane have been classified into different vessel types and tabulated in Table S1. Comparison between our measured EF results with the previous studies $3,10,12,15,18,28,29$ is presented in Figure 4. Field 

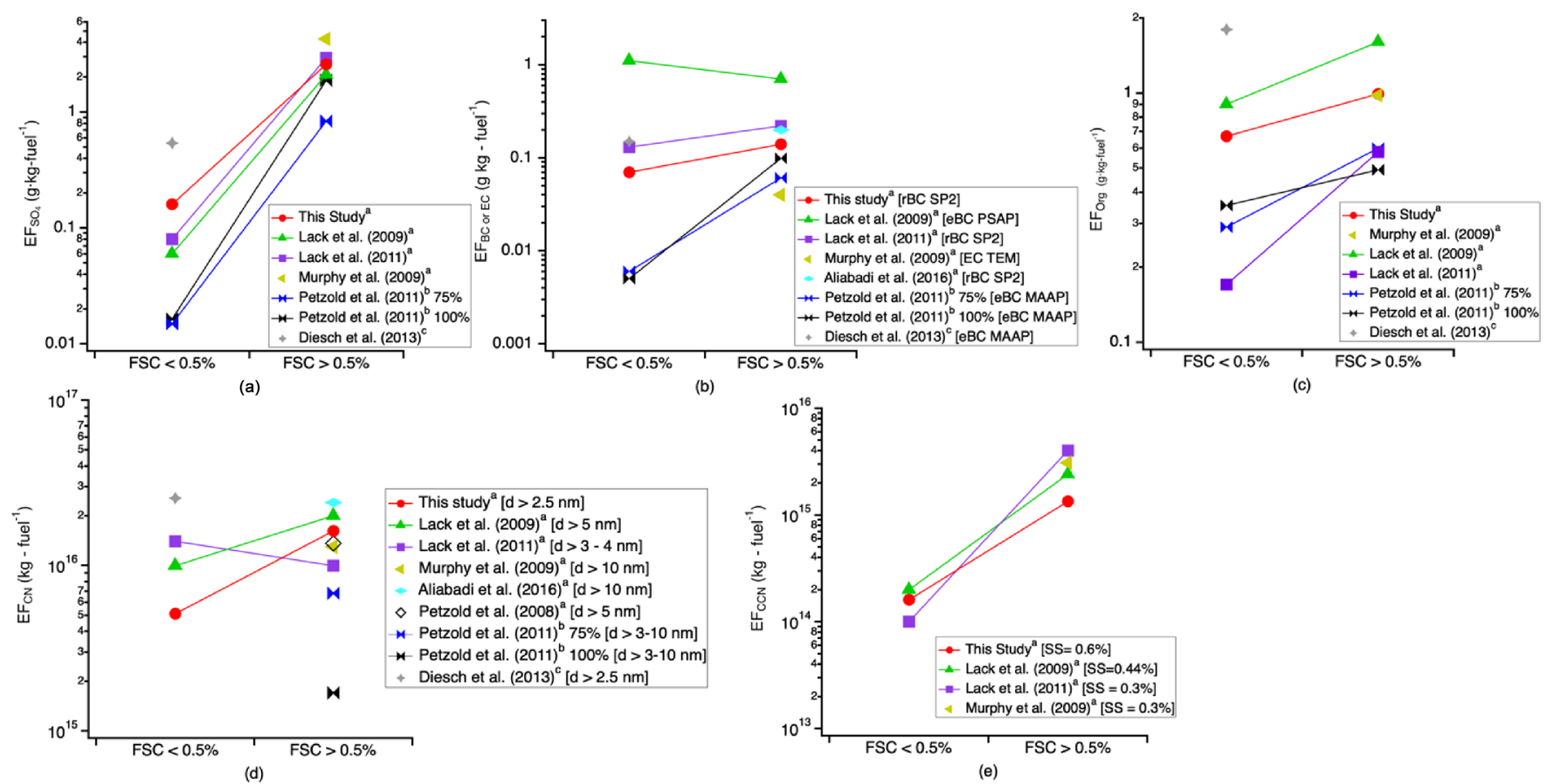

Figure 4. Comparison of the EF with previous studies for (a) $\mathrm{SO}_{4}$. (b) EF for $\mathrm{rBC}$ measured by a single particle soot photometer (SP2), equivalent $\mathrm{BC}(\mathrm{eBC})$ from a particle soot absorption photometer (PSAP) and a multiple angle absorption photometer (MAAP), and elemental carbon (EC) from transmission electron microscopy (TEM). (c) Organic compounds (Org) or organic carbon (OC). (d) Condensation nuclei (CN). (e) Cloud condensation nuclei $(\mathrm{CCN})$. EF results reported with the unit $\left[\mathrm{kWh}^{-1}\right]$ are converted to $\left[\mathrm{g} \mathrm{kg} \mathrm{fuel}{ }^{-1}\right]$ using the method described in the Supporting Information. The results of Petzold et al. ${ }^{12}$ is for MGO (FSC $<0.5 \%$ ) and HFO (FSC > 0.5\%) at a 75 and $100 \%$ engine load. The following superscript letters are as follows: field plume chasing measurement (a); testbed measurement (b); fixed station measurement (c).

measurements performed before 2012 (during which the maximum FSC in the OS was $4.5 \%$ ) and testbed studies are also included here.

Figure $3 \mathrm{a}$ shows that the directly emitted $\mathrm{SO}_{4}$ decreased when the apparent FSC decreased from being higher than 2.0\% to below $0.5 \%$, which agrees with previous studies. The decrease of sulfate emission due to a lower FSC at $0.5 \%$ is around 1 order of magnitude, as presented in Figure 4a. A slightly higher $\mathrm{SO}_{4}$ emission was observed at $\mathrm{FSC}<0.5 \%$ compared to the other studies, partly because of the potential usage of scrubbers ${ }^{31}$ and partly because some studies (Lack et al. ${ }^{10}$ and Petzold et al. ${ }^{12}$ ) were measuring with shipping fuels with an ultralow FSC (FSC < $0.1 \%$ ) only. With the lower apparent FSC (i.e., $\mathrm{SO}_{2}$ emission), the secondary $\mathrm{SO}_{4}$ formed from $\mathrm{SO}_{2}$ further downwind is expected to be reduced as well. The $S(V I)$ fraction shown in Figure $3 \mathrm{~h}$ is derived through the ratio between the $S(\mathrm{VI})$ mass and the total sulfur mass emitted. Unlike primary sulfate, the average $S(V I)$ fraction only decreased slightly with the reduction of the apparent FSC under a similar average engine load.

Figure $3 \mathrm{~b}$ shows that the average emission factor of $\mathrm{rBC}$ $\left(\mathrm{EF}_{\mathrm{rBC}}\right)$ decreased when shifting to the apparent $\mathrm{FSC}<0.5 \%$. However, the general trend of average $\mathrm{EF}_{\mathrm{rBC}}$ was not monotonic with respect to the apparent FSC as the decreasing $\mathrm{EF}_{\mathrm{rBC}}$ trend was also observed at FSC $>2 \%$. As shown in Figure $4 \mathrm{~b}$, while most of the studies observe a reduction trend, Lack et al. $^{28}$ observe an increase of $\mathrm{BC}$ emissions at FSC $<0.5 \%$. Currently, there is no clear evidence showing that the change of FSC will influence the $\mathrm{rBC}$ emissions, and it is more likely that the reduction of average $\mathrm{EF}_{\mathrm{rBC}}$ at $\mathrm{FSC}<0.5 \%$ was contributed by other causes rather than the sulfur content itself. Some ship engine testbed studies suggest that the usage of some types of alternative low-sulfur fuel or the application of the scrubbers may help to reduce the BC emissions. ${ }^{12,31,32}$ It should be noted that the $\mathrm{BC}$ concentration is quantified through different techniques in different studies, as shown in Figure $4 \mathrm{~b}$, and the absolute BC (or EC) concentrations largely depend on the methodology used. In general, our results agree with the previous SP2 study results.

Only slight variations in the average $\mathrm{EF}_{\mathrm{Org}}$ were observed at a different apparent FSC, and the average $\mathrm{EF}_{\mathrm{Org}}$ within each FSC bin has relatively large standard deviation (Figure 3c). Some studies also report slightly lower $\mathrm{EF}_{\mathrm{Org}}$ at $\mathrm{FSC}<0.5 \%$, as shown in Figure 4c, but the variations are limited, and this reduction is mainly due to the change of fuel type. Studies show that switching to various alternative low-sulfur fuels (i.e., biofuel or low-sulfur HFO) may lead to similar amounts of Org emissions as burning high-sulfur HFO (at the same engine load). ${ }^{12,33,34}$ Meanwhile, other factors such as the usage of lubricating oil will also influence the Org emissions under lower FSC conditions. ${ }^{18}$ In general, the results presented here indicate that the emission of Org was independent from the reduction in sulfur emissions.

Figure $3 \mathrm{~d}$ shows the variation of $\mathrm{EF}_{\mathrm{CN}>2.5 \mathrm{~nm}}$. There was a sharp decrease in the average $\mathrm{EF}_{\mathrm{CN}>2.5 \mathrm{~nm}}$ at apparent $\mathrm{FSC}$ $<0.5 \%$, whereas above an FSC of $1 \%$, the average $\mathrm{EF}_{\mathrm{CN}>2.5 \mathrm{~nm}}$ was largely invariant. The absolute $\mathrm{CN}$ emission results vary from different studies, as presented in Figure $4 b$, and the difference could be caused by the different measurement instruments and the dilution environment during the experiment. ${ }^{35}$ The reverse trend observed by Lack et al. ${ }^{10}$ is caused by the significant reduction of engine load. Our results and Lack et al. ${ }^{28}$ suggested that a lower FSC may result in lower $\mathrm{CN}$ emissions. The reduction of $\mathrm{EF}_{\mathrm{CN}>2.5 \mathrm{~nm}}$ at $\mathrm{FSC}<0.5 \%$ is 
partly due to the lower sulfate emissions as fuel quality is suggested to be a factor in the emissions of smaller particles. ${ }^{36}$ The EF for the CNs with $D_{\mathrm{p}}$ larger than $0.1 \mu \mathrm{m}\left(\mathrm{EF}_{\mathrm{CN}>0.1 \mu \mathrm{m}}\right)$ was derived through the PCASP and CDP measurements (Figure 4e). Combined with the observed variation of sizeresolved $\mathrm{EF}_{\mathrm{CN}}$ (Figure 3), it is clear that the reduction of sulfur emission will lead to substantial decreases of $\mathrm{CN}>0.1 \mu \mathrm{m}$ emissions.

Figure $3 \mathrm{f}$, g shows that both variations of average $\mathrm{EF}_{\mathrm{CCN}}$ and the ratio between the number concentrations of $\mathrm{CCN}$ and $\mathrm{CN}$ $>2.5 \mathrm{~nm}\left(\Delta \mathrm{CCN} / \Delta N_{\mathrm{CN}>2.5 \mathrm{~nm}}\right)$ have a positive relationship with the apparent FSC. The activation of CCN depends on both the particle size and composition. Mainly driven by the reduction of sulfate, the water-soluble fraction reduced and the calculated $\kappa$ decreased from 0.63 to 0.18 going from FSC $>0.5$ to $<0.5 \%$ (as shown in Table 1 ). Changes to both the particle

Table 1. Summary of Measured EFs and Aerosol Characteristics (Mean of Different Vessels \pm Standard Deviation $)^{a}$

\begin{tabular}{|c|c|c|c|}
\hline & $\begin{array}{c}\text { apparent FSC > } \\
0.5 \%[28]\end{array}$ & $\begin{array}{c}\text { apparent FSC < } \\
0.5 \%[6]\end{array}$ & $\begin{array}{c}\% \\
\text { change }\end{array}$ \\
\hline $\mathrm{SO}_{4}\left(\mathrm{~g} \mathrm{~kg} \mathrm{fuel}^{-1}\right)$ & $2.58( \pm 1.3)$ & $0.16( \pm 0.2)$ & $-94 \%$ \\
\hline $\mathrm{rBC}\left(\mathrm{g} \mathrm{kg} \mathrm{fuel}^{-1}\right)$ & $0.14( \pm 0.09)$ & $0.08( \pm 0.03)$ & $-43 \%$ \\
\hline Org (g kg fuel $\left.{ }^{-1}\right)$ & $0.99( \pm 0.49)$ & $0.66( \pm 0.4)$ & $-33 \%$ \\
\hline $\mathrm{PM}_{1}\left(\mathrm{~g} \mathrm{~kg} \mathrm{fuel}^{-1}\right)$ & $3.87( \pm 1.57)$ & $1.1( \pm 0.5)$ & $-72 \%$ \\
\hline $\begin{array}{l}\mathrm{CN}>2.5 \mathrm{~nm}(\# \mathrm{~kg} \\
\left.\text { fuel }^{-1}\right)\end{array}$ & $\begin{array}{l}1.62 \times 10^{16} \\
\left( \pm 0.7 \times 10^{16}\right)\end{array}$ & $\begin{array}{l}0.51 \times 10^{16} \\
\quad\left( \pm 0.38 \times 10^{16}\right)\end{array}$ & $-69 \%$ \\
\hline $\begin{array}{l}\mathrm{CN}>0.1 \mu \mathrm{m}(\# \mathrm{~kg} \\
\left.\text { fuel }^{-1}\right)\end{array}$ & $\begin{array}{c}5.4 \times 10^{14}( \pm 2.9 \times \\
\left.10^{14}\right)\end{array}$ & $\underset{\left.10^{14}\right)}{2.36 \times 10^{14}( \pm 1.2 \times}$ & $-56 \%$ \\
\hline 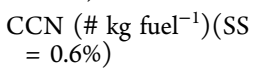 & $\begin{array}{l}1.34 \times 10^{15}( \pm 0.5 \\
\left.\times 10^{15}\right)\end{array}$ & $\begin{array}{l}0.16 \times 10^{15}( \pm 0.11 \\
\left.\quad \times 10^{15}\right)\end{array}$ & $-88 \%$ \\
\hline $\begin{array}{l}\Delta \mathrm{CCN} / \Delta N_{\mathrm{CN}>2.5 \mathrm{~nm}} \\
(\%)\end{array}$ & $7.8( \pm 2.6)$ & $3.0( \pm 1.6)$ & $-62 \%$ \\
\hline $\mathrm{S}(\mathrm{VI}) /$ total sulfur $(\%)$ & $4.7( \pm 2.1)$ & $2.6( \pm 0.9)$ & $-45 \%$ \\
\hline$\kappa$ & $0.63( \pm 0.12)$ & $0.18( \pm 0.08)$ & $-71 \%$ \\
\hline
\end{tabular}

${ }^{a}$ Measured vessel numbers were shown in group by an apparent FSC over and under $0.5 \%$. Measured vessel numbers were shown in the square brackets. For the plumes from single vessels sampled multiple times, the average of the multiple measurements is used. An apparent FSC of $0.5 \%$ is the IMO 2020 sulfur regulation limit for shipping in international waters.

size distribution and particle composition likely contributed to

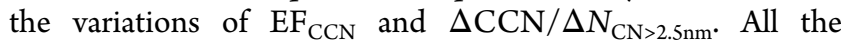

previous experimental results agree that there is a significant reduction of $\mathrm{CCN}$ emission when a shift to FSC $<0.5 \%$ is shown in Figure 4e, and the decrease is more than $80 \%$.

Evolution of the Ship Plume. In situ characterization of ship plume evolution within the marine boundary layer is also important for better understanding of the lifecycle and climate effects of ship-emitted particles. To investigate the evolution of the particles in ship plumes, the dispersion of the ship plumes was simulated by the U.K. Met Office NAME Lagrangian particle dispersion model, ${ }^{37}$ and details of the calculation of time downwind are presented in the Supporting Information. Only plumes with reported ship locations in the OS were included here. Figure 5a presents measurements of a single plume emitted from one oil tanker operating at its cruise speed. From near the point of emission to $\sim 50$ min later, $\Delta \mathrm{CCN} / \Delta N_{\mathrm{CN}>2.5 \mathrm{~nm}}$ increased from $\sim 5$ to $\sim 9 \%$, possibly due to the condensation of the secondary material increasing the sizes of the particles. The $\mathrm{EF}_{\mathrm{CN}>2.5 \mathrm{~nm}}$ decreased along the plume, albeit with lower statistical significance. The decreasing of $\mathrm{EF}_{\mathrm{CN}>2.5 \mathrm{~nm}}$ after $\sim 10$ min was partly due to the rapid coagulation of smaller particles. ${ }^{28,38}$ In addition to the growth of particle size, parcel model studies also predict that coagulation leads to particles being more internally mixed, which further contributes to the development of $\mathrm{CCN}$ activity. ${ }^{38}$ The results presented here show that the CCN concentrations evolve during the first stage of plume evolution, and ship-emitted CCN may be underestimated if these processes are neglected.

The average S(VI) fraction is $4.7( \pm 2.1) \%$ close to the ship emission point at $\mathrm{OS}$, and this conversion rate generally agrees with other studies, which indicates that the sulfur conversion rate is between 3.9 and $5.0 \%$ for FSC $>0.5 \%$ at a relatively high engine load. ${ }^{35,39,40}$ With increasing time downwind of the emission point, more $\mathrm{S}(\mathrm{IV})$ are converted to $\mathrm{S}(\mathrm{VI})$. The $\mathrm{S}(\mathrm{VI})$ fraction for 40 vessels at $O S$ is shown in Figure $5 \mathrm{~b}$. The sulfur conversion rate was around $23.4 \%$ per hour on average during the early stages (first hour) of plume evolution, and this conversion rate is similar to that reported by Lack et al., ${ }^{28}$ who showed that the sulfur conversion rate from ship emissions over the sea is $\sim 20-30 \%$ per hour. The co-emitted products such as $\mathrm{NO}_{x}$, together with water vapor, may increase the conversion rate of sulfur, and the sea salt within the marine boundary layer $(\mathrm{MBL})$ may also play an important role in the production of $\mathrm{S}(\mathrm{VI}){ }^{41,42}$
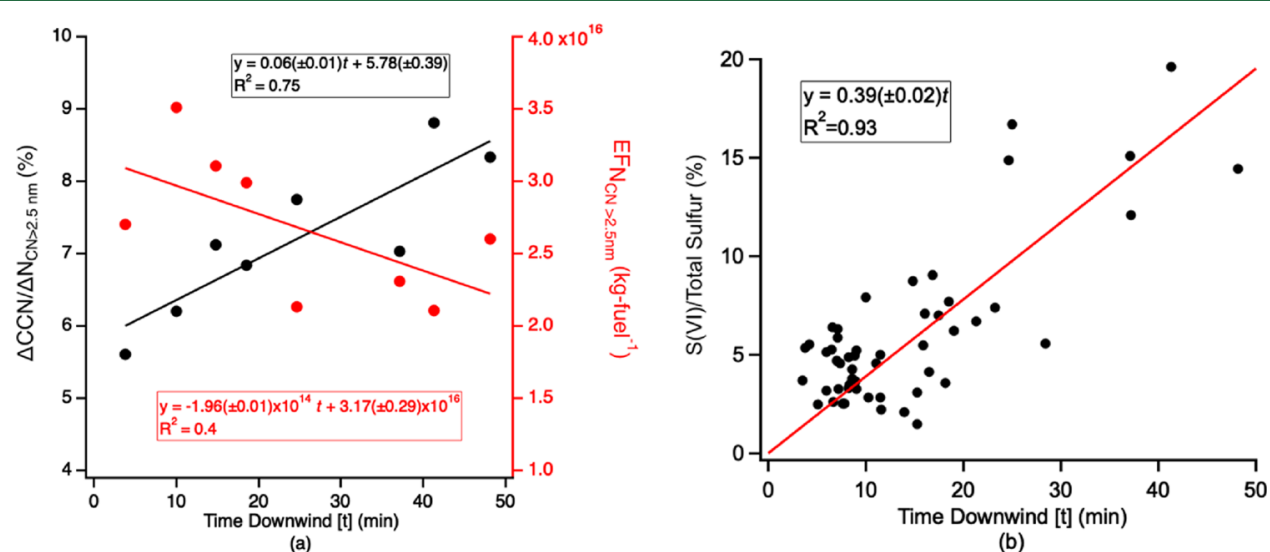

Figure 5. (a) $\Delta \mathrm{CCN} / \Delta N_{\mathrm{CN}>2.5 \mathrm{~nm}}$ and $\mathrm{EF}_{\mathrm{CN}>2.5 \mathrm{~nm}}$ as a function of time downwind for a single ship plume; (b) $\mathrm{S}$ (VI) fraction as a function of time downwind. 
Implications for the IMO 2020 Sulfur Regulation. The summary of all measured EFs, split by a threshold of $0.5 \%$ in the apparent FSC, during the whole ACRUISE campaign is presented in Table 1 . Note that most of the ship plumes with apparent FSC $<0.5 \%$ were measured within the SECA. In response to the new IMO 2020 regulation, the emission of total $\mathrm{CN}>2.5 \mathrm{~nm}$ may be reduced by $69 \%$, and the emitted $\mathrm{CN}>0.1 \mu \mathrm{m}$ was reduced by $56 \%$. Reductions of $\mathrm{SO}_{4}$ and total $\mathrm{PM}_{1}$ emissions observed were around 94 and $72 \%$, respectively. The $\mathrm{rBC}$ emissions decreased by $43 \%$, while the Org mass decreased by $33 \%$. As the variations of $\mathrm{rBC}$ and Org emission are not directly linked to the decrease of sulfur emissions, the variations are more likely to be caused by changes in the fuel quality and emission control technologies. There are currently no regulations regarding the $\mathrm{rBC}$ and Org components. Studies estimate that the ship-emitted BC accounts for around $2 \%$ of the $\mathrm{BC}$ emissions globally, and its impact on regional air quality is of much interest, ${ }^{43}$ so this may be the subject of future regulation. With a $71 \%$ reduction of $\kappa$ together with the shift of the particle size distribution toward smaller particles, the CCN emission and $\Delta \mathrm{CCN} / \Delta N_{\mathrm{CN}>2.5 \mathrm{~nm}}$ were observed to decrease by 88 and $62 \%$, respectively. Because of the economic benefits, ${ }^{44}$ ship owners may choose exhaust gas scrubbers as a means of compliance. Some of the measured ships might have been using scrubbers to meet the apparent FSC regulation within the European SECA. Experiments have confirmed that scrubbers are an effective control on $\mathrm{SO}_{x}$ and general $\mathrm{PM}$ emissions, ${ }^{31,32}$ but the potential secondary pollutants from the discharge of the scrubber may need to be addressed in the future studies. ${ }^{32,45}$

\section{ASSOCIATED CONTENT}

\section{SI Supporting Information}

The Supporting Information is available free of charge at https://pubs.acs.org/doi/10.1021/acs.est.0c04039.

The instrument list onboard the FAAM BAe-146 platform; calculation method for the emission factors, apparent fuel sulfur content, sulfur fraction, and hygroscopicity parameter $(\kappa)$; conversion of emission factors reporting in the unit $\left[\mathrm{g} \mathrm{kWh}^{-1}\right]$ or $\left[\mathrm{kWh}^{-1}\right]$; estimation of the vessel engine load; graph for the flight area and plume example; measured meteorological parameters; emission factors for different vessel types; Met Office NAME dispersion model setup; and calculation of plume downwind time (PDF)

\section{AUTHOR INFORMATION}

\section{Corresponding Authors}

Hugh Coe - Department of Earth and Environmental Sciences, University of Manchester, Manchester M13 9PL, U.K.; Email: hugh.coe@manchester.ac.uk

James D. Allan - Department of Earth and Environmental Sciences and National Centre for Atmospheric Sciences, University of Manchester, Manchester M13 9PL, U.K.; ๑ orcid.org/0000-0001-6492-4876; Email: james.allan@ manchester.ac.uk

\section{Authors}

Chenjie Yu - Department of Earth and Environmental Sciences, University of Manchester, Manchester M13 9PL, U.K.; (1) orcid.org/0000-0001-9831-4558
Dominika Pasternak - Wolfson Atmospheric Chemistry Laboratories, Department of Chemistry, University of York, York YO10 5DD, U.K.

James Lee - Wolfson Atmospheric Chemistry Laboratories, Department of Chemistry and National Centre for Atmospheric Sciences, University of York, York YO10 5DD, U.K.

Mingxi Yang - Plymouth Marine Laboratory, Plymouth PL1 3DH, U.K.

Thomas Bell - Plymouth Marine Laboratory, Plymouth PL1 3DH, U.K.; (1) orcid.org/0000-0002-4108-7048

Keith Bower - Department of Earth and Environmental Sciences, University of Manchester, Manchester M13 9PL, U.K.

Huihui Wu - Department of Earth and Environmental Sciences, University of Manchester, Manchester M13 9PL, U.K.

Dantong Liu - Department of Atmospheric Sciences, School of Earth Sciences, Zhejiang University, Zhejiang 310027, P. R. China; (1) orcid.org/0000-0003-3768-1770

Chris Reed - National Centre for Atmospheric Sciences, FAAM Airborne Laboratory, Cranfield MK43 0AL, U.K.; (1) orcid.org/0000-0002-9886-5875

Stéphane Bauguitte - National Centre for Atmospheric Sciences, FAAM Airborne Laboratory, Cranfield MK43 OAL, U.K.

Sam Cliff - National Centre for Atmospheric Sciences, FAAM Airborne Laboratory, Cranfield MK43 OAL, U.K.

Jamie Trembath - National Centre for Atmospheric Sciences, FAAM Airborne Laboratory, Cranfield MK43 OAL, U.K.

Complete contact information is available at:

https://pubs.acs.org/10.1021/acs.est.0c04039

\section{Notes}

The authors declare no competing financial interest.

\section{ACKNOWLEDGMENTS}

Airborne data were obtained using the FAAM BAe-146 Atmospheric Research Aircraft, which was operated by Airtask and jointly funded by the U.K. Natural Environment Research Council (NERC) and the Met Office. This work was funded by the NERC project ACRUISE (grant refs NE/S004467/1), part of the highlight topic "Impacts of future ship traffic and emission regulations upon gas-phase chemistry, aerosol composition, and radiative forcing in the North Atlantic and Arctic atmosphere".

\section{REFERENCES}

(1) Eyring, V.; Köhler, H. W.; Lauer, A.; Lemper, B. Emissions from international shipping: 2. Impact of future technologies on scenarios until 2050. J. Geophys. Res.: Atmos. 2005, 110, D17306.

(2) Eyring, V.; Köhler, H. W.; van Aardenne, J.; Lauer, A. Emissions from international shipping: 1 . The last 50 years. J. Geophys. Res.: Atmos. 2005, 110, D17305-1.

(3) Murphy, S. M.; Agrawal, H.; Sorooshian, A.; Padró, L. T.; Gates, H.; Hersey, S.; Welch, W. A.; Jung, H.; Miller, J. W.; Cocker, D. R., III; Nenes, A.; Jonsson, H. H.; Flagan, R. C.; Seinfeld, J. H. Comprehensive Simultaneous Shipboard and Airborne Characterization of Exhaust from a Modern Container Ship at Sea. Environ. Sci. Technol. 2009, 43, 4626-4640.

(4) Lauer, A.; Eyring, V.; Hendricks, J.; Jöckel, P.; Lohmann, U. Global model simulations of the impact of ocean-going ships on aerosols, clouds, and the radiation budget. Atmos. Chem. Phys. 2007, 7, 5061-5079. 
(5) Eyring, V.; Isaksen, I. S. A.; Berntsen, T.; Collins, W. J.; Corbett, J. J.; Endresen, O.; Grainger, R. G.; Moldanova, J.; Schlager, H.; Stevenson, D. S. Transport impacts on atmosphere and climate: Shipping. Atmos. Environ. 2010, 44, 4735-4771.

(6) Winebrake, J. J.; Corbett, J. J.; Green, E. H.; Lauer, A.; Eyring, V. Mitigating the Health Impacts of Pollution from Oceangoing Shipping: An Assessment of Low-Sulfur Fuel Mandates. Environ. Sci. Technol. 2009, 43, 4776-4782.

(7) Sofiev, M.; Winebrake, J. J.; Johansson, L.; Carr, E. W.; Prank, M.; Soares, J.; Vira, J.; Kouznetsov, R.; Jalkanen, J. P.; Corbett, J. J. Cleaner fuels for ships provide public health benefits with climate tradeoffs. Nat. Commun. 2018, 9, 406.

(8) Corbett, J. J.; Winebrake, J. J.; Green, E. H.; Kasibhatla, P.; Eyring, V.; Lauer, A. Mortality from Ship Emissions: A Global Assessment. Environ. Sci. Technol. 2007, 41, 8512-8518.

(9) Viana, M.; Hammingh, P.; Colette, A.; Querol, X.; Degraeuwe, B.; de Vlieger, I.; van Aardenne, J. Impact of maritime transport emissions on coastal air quality in Europe. Atmos. Environ. 2014, 90, 96-105.

(10) Lack, D. A.; Cappa, C. D.; Langridge, J.; Bahreini, R.; Buffaloe, G.; Brock, C.; Cerully, K.; Coffman, D.; Hayden, K.; Holloway, J.; Lerner, B.; Massoli, P.; Li, S. M.; McLaren, R.; Middlebrook, A. M.; Moore, R.; Nenes, A.; Nuaaman, I.; Onasch, T. B.; Peischl, J.; Perring, A.; Quinn, P. K.; Ryerson, T.; Schwartz, J. P.; Spackman, R.; Wofsy, S. C.; Worsnop, D.; Xiang, B.; Williams, E. Impact of fuel quality regulation and speed reductions on shipping emissions: implications for climate and air quality. Environ. Sci. Technol. 2011, 45, 90529060.

(11) Cappa, C. D.; Williams, E. J.; Lack, D. A.; Buffaloe, G. M.; Coffman, D.; Hayden, K. L.; Herndon, S. C.; Lerner, B. M.; Li, S. M.; Massoli, P.; McLaren, R.; Nuaaman, I.; Onasch, T. B.; Quinn, P. K. A case study into the measurement of ship emissions from plume intercepts of the NOAA ship Miller Freeman. Atmos. Chem. Phys. 2014, 14, 1337-1352.

(12) Petzold, A.; Lauer, P.; Fritsche, U.; Hasselbach, J.; Lichtenstern, M.; Schlager, H.; Fleischer, F. Operation of marine diesel engines on biogenic fuels: modification of emissions and resulting climate effects. Environ. Sci. Technol. 2011, 45, 10394-10400.

(13) Buffaloe, G. M.; Lack, D. A.; Williams, E. J.; Coffman, D.; Hayden, K. L.; Lerner, B. M.; Li, S. M.; Nuaaman, I.; Massoli, P.; Onasch, T. B.; Quinn, P. K.; Cappa, C. D. Black carbon emissions from in-use ships: a California regional assessment. Atmos. Chem. Phys. 2014, 14, 1881-1896.

(14) Aksoyoglu, S.; Baltensperger, U.; Prévôt, A. S. H. Contribution of ship emissions to the concentration and deposition of air pollutants in Europe. Atmos. Chem. Phys. 2016, 16, 1895-1906.

(15) Petzold, A.; Hasselbach, J.; Lauer, P.; Baumann, R.; Franke, K.; Gurk, C.; Schlager, H.; Weingartner, E. Experimental studies on particle emissions from cruising ship, their characteristic properties, transformation and atmospheric lifetime in the marine boundary layer. Atmos. Chem. Phys. 2008, 8, 2387-2403.

(16) Beecken, J.; Mellqvist, J.; Salo, K.; Ekholm, J.; Jalkanen, J. P.; Johansson, L.; Litvinenko, V.; Volodin, K.; Frank-Kamenetsky, D. A. Emission factors of $\mathrm{SO}_{2}, \mathrm{NO}_{x}$ and particles from ships in Neva Bay from ground-based and helicopter-borne measurements and AISbased modeling. Atmos. Chem. Phys. 2015, 15, 5229-5241.

(17) Zetterdahl, M.; Moldanová, J.; Pei, X.; Pathak, R. K.; Demirdjian, B. Impact of the $0.1 \%$ fuel sulfur content limit in SECA on particle and gaseous emissions from marine vessels. Atmos. Environ. 2016, 145, 338-345.

(18) Diesch, J. M.; Drewnick, F.; Klimach, T.; Borrmann, S. Investigation of gaseous and particulate emissions from various marine vessel types measured on the banks of the Elbe in Northern Germany. Atmos. Chem. Phys. 2013, 13, 3603-3618.

(19) Crippa, M.; Guizzardi, D.; Muntean, M.; Schaaf, E.; Dentener, F.; van Aardenne, J. A.; Monni, S.; Doering, U.; Olivier, J. G. J.; Pagliari, V.; Janssens-Maenhout, G. Gridded emissions of air pollutants for the period 1970-2012 within EDGAR v4.3.2. Earth Syst. Sci. Data 2018, 10, 1987-2013.
(20) Drewnick, F.; Hings, S. S.; DeCarlo, P.; Jayne, J. T.; Gonin, M.; Fuhrer, K.; Weimer, S.; Jimenez, J. L.; Demerjian, K. L.; Borrmann, S.; Worsnop, D. R. A New Time-of-Flight Aerosol Mass Spectrometer (TOF-AMS) - Instrument Description and First Field Deployment. Aerosol Sci. Technol. 2005, 39, 637-658.

(21) Guo, H.; Campuzano-Jost, P.; Nault, B. A.; Day, D. A.; Schroder, J. C.; Dibb, J. E.; Dollner, M.; Weinzierl, B.; Jimenez, J. L. The Importance of Size Ranges in Aerosol Instrument Intercomparisons: A Case Study for the ATom Mission. Atmos. Meas. Tech. Discuss. 2020, 2020, 1-49.

(22) McMeeking, G. R.; Hamburger, T.; Liu, D.; Flynn, M.; Morgan, W. T.; Northway, M.; Highwood, E. J.; Krejci, R.; Allan, J. D.; Minikin, A.; Coe, H. Black carbon measurements in the boundary layer over western and northern Europe. Atmos. Chem. Phys. 2010, 10, 9393-9414.

(23) Taylor, J. W.; Choularton, T. W.; Blyth, A. M.; Flynn, M. J.; Williams, P. I.; Young, G.; Bower, K. N.; Crosier, J.; Gallagher, M. W.; Dorsey, J. R.; Liu, Z.; Rosenberg, P. D. Aerosol measurements during COPE: composition, size, and sources of CCN and INPs at the interface between marine and terrestrial influences. Atmos. Chem. Phys. 2016, 16, 11687-11709.

(24) O'Shea, S. J.; Bauguitte, S. J.-B.; Gallagher, M. W.; Lowry, D.; Percival, C. J. Development of a cavity-enhanced absorption spectrometer for airborne measurements of $\mathrm{CH}_{4}$ and $\mathrm{CO}_{2}$. Atmos. Meas. Tech. 2013, 6, 1095-1109.

(25) Pollack, I. B.; Lerner, B. M.; Ryerson, T. B. Evaluation of ultraviolet light-emitting diodes for detection of atmospheric $\mathrm{NO}_{2}$ by photolysis - chemiluminescence. J. Atmos. Chem. 2010, 65, 111-125.

(26) Luke, W. T. Evaluation of a commercial pulsed fluorescence detector for the measurement of low-level $\mathrm{SO}_{2}$ concentrations during the Gas-Phase Sulfur Intercomparison Experiment. J. Geophys. Res.: Atmos. 1997, 102, 16255-16265.

(27) Alföldy, B.; Lööv, J. B.; Lagler, F.; Mellqvist, J.; Berg, N.; Beecken, J.; Weststrate, H.; Duyzer, J.; Bencs, L.; Horemans, B.; Cavalli, F.; Putaud, J.-P.; Janssens-Maenhout, G.; Csordás, A. P.; Van Grieken, R.; Borowiak, A.; Hjorth, J. Measurements of air pollution emission factors for marine transportation in SECA. Atmos. Meas. Tech. 2013, 6, 1777-1791.

(28) Lack, D. A.; Corbett, J. J.; Onasch, T.; Lerner, B.; Massoli, P.; Quinn, P. K.; Bates, T. S.; Covert, D. S.; Coffman, D.; Sierau, B.; Herndon, S.; Allan, J.; Baynard, T.; Lovejoy, E.; Ravishankara, A. R.; Williams, E. Particulate emissions from commercial shipping: Chemical, physical, and optical properties. J. Geophys. Res. 2009, 114, D00F04.

(29) Aliabadi, A. A.; Thomas, J. L.; Herber, A. B.; Staebler, R. M.; Leaitch, W. R.; Schulz, H.; Law, K. S.; Marelle, L.; Burkart, J.; Willis, M. D.; Bozem, H.; Hoor, P. M.; Köllner, F.; Schneider, J.; Levasseur, M.; Abbatt, J. P. D. Ship emissions measurement in the Arctic by plume intercepts of the Canadian Coast Guard icebreaker Amundsen from the Polar 6 aircraft platform. Atmos. Chem. Phys. 2016, 16, 7899-7916.

(30) Petters, M. D.; Kreidenweis, S. M. A single parameter representation of hygroscopic growth and cloud condensation nucleus activity - Part 2: Including solubility. Atmos. Chem. Phys. 2008, 8, $6273-6279$.

(31) Lehtoranta, K.; Aakko-Saksa, P.; Murtonen, T.; Vesala, H.; Ntziachristos, L.; Rönkkö, T.; Karjalainen, P.; Kuittinen, N.; Timonen, H. Particulate Mass and Nonvolatile Particle Number Emissions from Marine Engines Using Low-Sulfur Fuels, Natural Gas, or Scrubbers. Environ. Sci. Technol. 2019, 53, 3315-3322.

(32) Fridell, E.; Salo, K. Measurements of abatement of particles and exhaust gases in a marine gas scrubber. Proc. Inst. Mech. Eng., Part M J. Eng. Marit. Environ. 2014, 230, 154-162.

(33) Zhang, X.; Zhang, Y.; Liu, Y.; Zhao, J.; Zhou, Y.; Wang, X.; Yang, X.; Zou, Z.; Zhang, C.; Fu, Q.; Xu, J.; Gao, W.; Li, N.; Chen, J. Changes in the $\mathrm{SO}_{2}$ Level and $\mathrm{PM}_{2.5}$ Components in Shanghai Driven by Implementing the Ship Emission Control Policy. Environ. Sci. Technol. 2019, 53, 11580-11587. 
(34) Streibel, T.; Schnelle-Kreis, J.; Czech, H.; Harndorf, H.; Jakobi, G.; Jokiniemi, J.; Karg, E.; Lintelmann, J.; Matuschek, G.; Michalke, B.; Müller, L.; Orasche, J.; Passig, J.; Radischat, C.; Rabe, R.; Reda, A.; Rüger, C.; Schwemer, T.; Sippula, O.; Stengel, B.; Sklorz, M.; Torvela, T.; Weggler, B.; Zimmermann, R. Aerosol emissions of a ship diesel engine operated with diesel fuel or heavy fuel oil. Environ. Sci. Pollut. Res. 2017, 24, 10976-10991.

(35) Petzold, A.; Weingartner, E.; Hasselbach, J.; Lauer, P.; Kurok, C.; Fleischer, F. Physical Properties, Chemical Composition, and Cloud Forming Potential of Particulate Emissions from a Marine Diesel Engine at Various Load Conditions. Environ. Sci. Technol. 2010, 44, 3800-3805.

(36) Winnes, H.; Fridell, E. Particle emissions from ships: dependence on fuel type. J. Air Waste Manage. Assoc. 2009, 59, 1391-1398.

(37) Jones, A.; Thomson, D.; Hort, M.; Devenish, B. The U.K. Met Office's Next-Generation Atmospheric Dispersion Model, NAME III. In Air Pollution Modeling and Its Application XVII; Borrego, C.; Norman, A.-L., Eds.; Springer US: Boston, MA, 2007; pp. 580-589.

(38) Tian, J.; Riemer, N.; West, M.; Pfaffenberger, L.; Schlager, H.; Petzold, A. Modeling the evolution of aerosol particles in a ship plume using PartMC-MOSAIC. Atmos. Chem. Phys. 2014, 14, 5327-5347.

(39) Agrawal, H.; Welch, W. A.; Miller, J. W.; Cocker, D. R. Emission Measurements from a Crude Oil Tanker at Sea. Environ. Sci. Technol. 2008, 42, 7098-7103.

(40) Agrawal, H.; Malloy, Q. G. J.; Welch, W. A.; Wayne Miller, J.; Cocker, D. R., III In-use gaseous and particulate matter emissions from a modern ocean going container vessel. Atmos. Environ. 2008, $42,5504-5510$.

(41) Faloona, I.; Conley, S. A.; Blomquist, B.; Clarke, A. D.; Kapustin, V.; Howell, S.; Lenschow, D. H.; Bandy, A. R. Sulfur dioxide in the tropical marine boundary layer: dry deposition and heterogeneous oxidation observed during the Pacific Atmospheric Sulfur Experiment. J. Atmos. Chem. 2009, 63, 13-32.

(42) Dominguez, G.; Jackson, T.; Brothers, L.; Barnett, B.; Nguyen, B.; Thiemens, M. H. Discovery and measurement of an isotopically distinct source of sulfate in Earth's atmosphere. Proc. Natl. Acad. Sci. 2008, 105, 12769.

(43) Bond, T. C.; Doherty, S. J.; Fahey, D. W.; Forster, P. M.; Berntsen, T.; DeAngelo, B. J.; Flanner, M. G.; Ghan, S.; Kärcher, B.; Koch, D.; Kinne, S.; Kondo, Y.; Quinn, P. K.; Sarofim, M. C.; Schultz, M. G.; Schulz, M.; Venkataraman, C.; Zhang, H.; Zhang, S.; Bellouin, N.; Guttikunda, S. K.; Hopke, P. K.; Jacobson, M. Z.; Kaiser, J. W.; Klimont, Z.; Lohmann, U.; Schwarz, J. P.; Shindell, D.; Storelvmo, T.; Warren, S. G.; Zender, C. S. Bounding the role of black carbon in the climate system: A scientific assessment. J. Geophys. Res.: Atmos. 2013, $118,5380-5552$.

(44) Jiang, L.; Kronbak, J.; Christensen, L. P. The costs and benefits of sulphur reduction measures: Sulphur scrubbers versus marine gas oil. Transp. Res. Part D Transp. Environ. 2014, 28, 19-27.

(45) Ytreberg, E.; Hassellöv, I.-M.; Nylund, A. T.; Hedblom, M.; AlHandal, A. Y.; Wulff, A. Effects of scrubber washwater discharge on microplankton in the Baltic Sea. Mar. Pollut. Bull. 2019, 145, 316324. 